\title{
Influence of temperature on germination of Japanese brome seed
}

\author{
MARSHALL R. HAFERKAMP, DEBRA PALMQUIST, JAMES A. YOUNG, AND MICHAEL \\ D. MACNEIL
}

Authors are rangeland scientist, USDA-ARS, Fort Keogh Livestock and Range Research Laboratory, Miles City, Mont. 59301; statistician and rangeland scientist, USDA-ARS, 920 Valley Road, Reno, Nev. 89512; and research geneticist, USDA-ARS, Fort Keogh Livestock and Range Research Laboratony, Miles City, Mont. 59301.

\begin{abstract}
Japanese brome (Bromus japonicus Thunb.), an introduced annual grass, is now common in some northern mixed-prairie communities. This species has the potential to alter both the seasonality of standing crop and forage quality. We sought to gain a greater understanding of Japanese brome seed germination by subjecting seed to a series of 55 constant or alternating temperature regimes following 3 to 9 months of dry laboratory storage. Cold and moderate temperature regimes provided optimum germination conditions (defined as not lower than the maximum observed minus one-half its confidence interval at the $\mathbf{0 . 0 5}$ level of probability). Extremely cold or warm temperatures suppressed germination. Germination of afterripened seed over a wide range of temperature combinations, many of which occur during fall in the Northern Great Plains, should enhance establishment and perpetuation of Japanese brome on rangelands.
\end{abstract}

Key Words: Bromus japonicus, Great Plains

Japanese brome (Bromus japonicus Thunb.), an introduced weedy grass, has invaded some mixed-prairie communities in the Northern Great Plains (Haferkamp et al. 1993, Whisenant 1990). Its life cycle is short in comparison to coexisting perennial grasses like western wheatgrass [Pascopyrum smithii Rydb. (Love)]. As with all annual grasses, Japanese brome herbage production is erratic from year to year (Hull and Pehanec 1947). Thus, presence of Japanese brome plants may shift the period of peak forage production, causing an earlier decline in overall forage quality (Cook and Harris 1952).

Perpetuation of Japanese brome depends on high seed production and propagation when environmental conditions are favor-

\footnotetext{
The authors express appreciation to Bill Creamer, Cheryl Murphy and several summer aids for assistance with seed collection and Ellen Martens for germination counts.

This paper is a contribution from the USDA, ARS and Montana Agr. Exp. Sta. Miles City, Mont.

USDA, ARS, Northern Plains Area, is an equal opportunity/affirmative action employer, and all agency services are available without discrimination.

Publication has been approved by the Durector of the Montana Agr. Exp. Sta. Joumal Ser. J-2889.

Manuscript Accepted 10 Nov. 1994.
}

able. Determining temperature profiles for optimal germination of Japanese brome is one step in developing a better understanding of the population dynamics of this species. Understanding this phenomena is essential for developing effective schemes for managing Japanese brome infested rangeland.

Baskin and Baskin (1981) found Japanese brome seeds collected during August through November in south central Kentucky germinated nearly $100 \%$ during a 30 -day incubation period in varying environments. Light conditions were either alternating (14/10 hours) light and darkness. Incubation temperature combinations of $12 / 12$ hours were $6 / 15,10 / 20,15 / 30$, and $20 / 35^{\circ} \mathrm{C}$ which represented seedbed temperatures from late June until mid December.

In this study, we determined temperature profiles for germination of Japanese brome seeds collected in Montana during July and August and stored for 3 to 9 months. These seeds are representative of those disseminated during the period spanning late summer to early fall.

\section{Materials and Methods}

Japanese brome seeds were collected from native rangeland located on the Fort Keogh Livestock and Range Research Laboratory in Miles City, Mont. Collections were made on 10 , 13, and 25 July and 2 Aug. 1990 and 12, 18, and 25 July and 1 Aug. 1991. Seeds were stored in paper sacks in the laboratory at about $21^{\circ} \mathrm{C}$ until germination trials were run in Reno, Nev., 3 to 9 months following collection. Seed was cleaned by hand in fall after all collections had been made each year. Storage or afterripening was of sufficient duration to remove primary dormancy reported for brome seeds collected in July (Hull and Hansen 1974, Baskin and Baskin 1981).

Four replications of 25 seeds from each collection date were incubated for 4 weeks in closed petri dishes on $1 \mathrm{~mm}$ thick filter paper moistened with distilled water. Dishes were arranged in a randomized-complete-block design, in 10 dark incubators. Constant incubator temperatures included $0,2,5$ and all $5^{\circ} \mathrm{C}$ increments through $40^{\circ} \mathrm{C}$. Alternating regimes were attained by moving dishes between incubators using 16 hours at each constant temperature plus 8 hours at all possible higher temperatures. 
For example $35^{\circ} \mathrm{C}$ was alternated with only $40^{\circ} \mathrm{C}$, while $0^{\circ} \mathrm{C}$ was alternated with $2,5,10,15,20,25,30,35$, and $40^{\circ} \mathrm{C}$. Germination counts were taken weekly, and seeds were considered germinated when the radicle was at least $5 \mathrm{~mm}$ long.

Data from each base temperature and its alternating temperature regime were used to develop regression equations of quadratic response surfaces with estimated germination means and confidence intervals at the $5 \%$ level of probability (Evans et al. 1982). A number of germination parameters were synthesized from these quadratic response surfaces (Young and Evans 1982) to assist in interpretation of germination temperature profiles. These included: mean germination, percentage of regimes with some germination, optimum germination, percentage of regimes with optimum germination, mean of optima, maximum germination, and frequency of optima (Young et al. 1992). The 8 quadratic equations consisted of the 4 collections made during 2 different years, 1990 and 1991. To determine if germination differences existed between accessions within a year and accessions between years, standard partial F-tests were conducted and resulting differences determined by nonoverlapping confidence levels at the 5\% level (Evans et al. 1982, Palmquist et al. 1987).

For presentation in tables, data were grouped into temperature regimes (minimum/maximum) that simulated natural seedbed environments occurring across a wide array of geographic locations based on seedbed monitoring studies (Evans et al. 1970, Evans and Young 1970, 1972, Young and Evans 1982). These temperature regime groupings are:

1. very cold $\left(0 / 0,0 / 2,0 / 5\right.$, and $\left.2 / 2{ }^{\circ} \mathrm{C}\right)$;

2. cold $\left(0 / 10,0 / 15,2 / 5,2 / 10,2 / 15,5 / 5\right.$, and $\left.5 / 10^{\circ} \mathrm{C}\right)$;

3. cold fluctuating $\left(0 / 20\right.$, through $0 / 40^{\circ} \mathrm{C}$ and $2 / 20$ through $2 / 40^{\circ} \mathrm{C}$ );

4. fluctuating $\left(5 / 30\right.$ through $5 / 40^{\circ} \mathrm{C}, 10 / 35,10 / 40$, and $\left.15 / 40^{\circ} \mathrm{C}\right)$;

5. moderate $\left(5 / 15\right.$ through $5 / 25^{\circ} \mathrm{C}, 10 / 10$ through $10 / 30^{\circ} \mathrm{C}$, $5 / 15$ through $5 / 30^{\circ} \mathrm{C}, 20 / 20$ through $20 / 35^{\circ} \mathrm{C}, 25 / 25$, and $\left.25 / 30^{\circ} \mathrm{C}\right)$;

6. warm $\left(20 / 40,25 / 35\right.$, and $25 / 40^{\circ} \mathrm{C}, 30 / 30$ through $30 / 40^{\circ} \mathrm{C}$, $35 / 35,35 / 40$, and $40 / 40^{\circ} \mathrm{C}$ ).

\section{Results and Discussion}

Mean germination of Japanese brome seed from the 55-temperature profiles averaged across the 8 collection dates was $71 \pm 4.0 \%$. Some germination occurred in $96 \pm 1.4 \%$ of the temperature regimes, and the mean germination for regimes where some germination occurred was $74 \pm 4.0 \%$. Optimal germination (defined as germination not lower than the maximum observed minus one-half its confidence interval at 0.05 level of probability) occurred in $32 \pm 8.3 \%$ of the regimes, and the mean of the optima

Table 1. Frequency of optimum germination $(99 \%)$ for Japanese brome seed collected in Montana in summer 1990-91.

\begin{tabular}{lc}
\hline \hline Temperature regimes & Frequency \\
\hline $5-10 / 15,5-15 / 20,10-15 / 25^{\circ} \mathrm{C}$ & $-\%--$ \\
$2 / 15,0-2$ and $20 / 20,5$ and $20 / 25,15 / 30^{\circ} \mathrm{C}$ & 100 \\
$0 / 15,2 / 25,10 / 30^{\circ} \mathrm{C}$ & 83 \\
$15 / 15,20 / 30^{\circ} \mathrm{C}$ & 75 \\
\hline
\end{tabular}

was $99 \pm 1.1 \%$. The maximum observed germination was $100 \pm 0.4 \%$. These findings suggest temperature does not appear to restrict germination once seeds are afterripened. Others have reported the temperature range favoring germination of many species narrows as dormancy intensifies and expands as dormancy declines (Vegis 1964).

Optimum temperatures for germination of Japanese brome seed were constant $20^{\circ} \mathrm{C}$ and alternating minimum/maximum regimes of $2-10 / 15,0-15 / 20,5-20 / 25$, and $15 / 30^{\circ} \mathrm{C}$ (Table 1). Over $75 \%$ of the collections produced optimum germination in these regimes.

The partial F-test comparison of regression equations across both years (1990 and 1991) and collections (A, B, C, and D) leads to the conclusion that germination response to temperature regimes was not homogenous ( $P \leq 0.01)$. Likewise, partial F-tests for collections A, B, C, and D for 1990 alone leads to similar conclusions $(P \leq 0.05)$ concerning the homogeneity of responses among collections within year and for 1991. Thus, there are germination differences between collections within a year and between the 2 years tested. Response surfaces developed for Japanese brome germination as a function of minimum and maximum incubation temperature treatments are given:

\begin{tabular}{|c|c|c|}
\hline & Collection & $\mathrm{R}^{2}$ \\
\hline A & 10 Jul. 1990 & 0.83 \\
\hline B & 13 Jul. 1990 & 0.80 \\
\hline C & 25 Jul. 1990 & 0.71 \\
\hline D & 02 Aug. 1990 & 0.74 \\
\hline A & 12 Jul. 1991 & 0.74 \\
\hline B & 18 Jul. 1991 & 0.77 \\
\hline C & 25 Jul. 1991 & 0.80 \\
\hline D & Ol Aug. 1991 & 0.80 \\
\hline
\end{tabular}

Where $\mathrm{Y}=$ Estimated $\%$ germination

\begin{tabular}{|c|}
\hline $\begin{array}{l}\text { Equation } \\
Y=10.77-0.15 X_{1}+9.61 X_{2}-0.12 X_{1}{ }^{2} \\
0.25 X_{2}{ }^{2}+0.11 X_{1} X_{2} \\
Y=14.23-0.50 X_{1}+9.28 X_{2}-0.13 X_{1}{ }^{2} \\
0.24 X_{2}{ }^{2}+0.14 X_{1} X_{2} \\
Y=44.52-0.58 X_{1}+6.79 X_{2}-0.15 X_{1}{ }^{2} \\
0.20 X_{2}{ }^{2}+0.16 X_{1} X_{2} \\
Y=36.85-0.35 X_{1}+7.22 X_{2}-0.17 X_{1}{ }^{2} \\
0.21 X_{2}{ }^{2}+0.18 X_{1} X_{2} \\
Y=49.62-0.64 X_{1}+4.57 X_{2}-0.16 X_{1}{ }^{2} \\
0.15 X_{2}{ }^{2}+0.14 X_{1} X_{2} \\
Y=52.48-0.14 X_{1}+5.75 X_{2}-0.18 X_{1}{ }^{2}- \\
0.18 X_{2}{ }^{2}+0.17 X_{1} X_{2} \\
Y=9.47-0.45 X_{1}+8.97 X_{2}-0.19 X_{1}{ }^{2} \\
0.24 X_{2}{ }^{2}+0.18 X_{1} X_{2} \\
Y=24.00-0.25 X_{1}+8.07 X_{2}-0.16 X_{1}{ }^{2} \\
0.22 X_{2}{ }^{2}+0.15 X_{1} X_{2}\end{array}$ \\
\hline
\end{tabular}

$\mathrm{X}_{1}=$ Minimum (nighttime) temperature, and

$\mathrm{X}_{2}=$ Maximum (daytime) temperature.

Representative response surfaces occur for 1991 A and B (Fig. 1). The response surface for $1991 \mathrm{~A}$ is unique, in that, $100 \%$ ger-
ER:AA A :99:

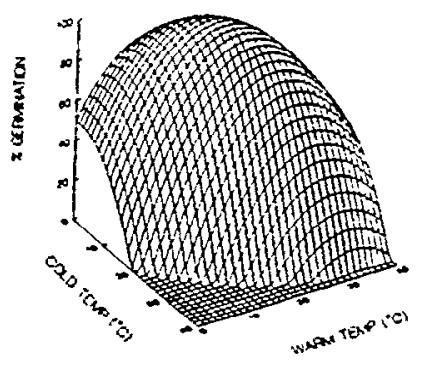

59.25 -39

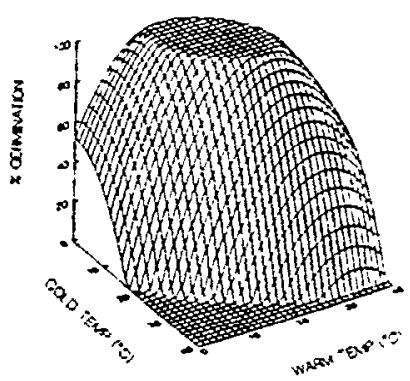

Fig. 1. Representative response surfaces of percent germination for Japanese brome seed collected in Montana in 1990 and 1991, as a function of cold (simulated nighttime) temperature and warm (simulated daytime) temperature. 
Table 2. Estimated percent germination of Japanese brome for year, collection, temperature regines subclasses from response surface analysis.

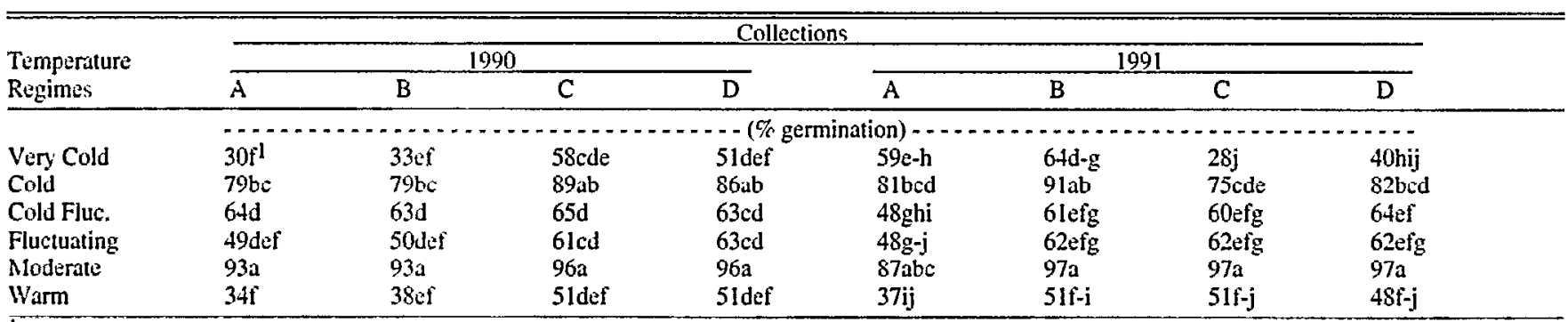

'Evtmated percent germination hetween year)-by'collections-by-lemperature regimes is not significantly different if followed by the same letter(s). as determined by' overlap of their comesponding confidence inter als at $P<0.05$.

mination was not attained. All others were similar to $1991 \mathrm{~B}$ where $100 \%$ germination was attained ov'er several temperatures.

To determine where germination differences are occurring, confidence intervals for estimated mean percent germination for temperature regimes (Fig. 2) were derived from the response surface equation and compared (Table 2). Maximum germination of Japanese brome seed occurred at moderate and cold seedbed conditions with germination being somewhat depressed in very cold and warmer than moderate temperatures (Table 2). Although, differences existed between collections, in general responses followed similar trends between years.

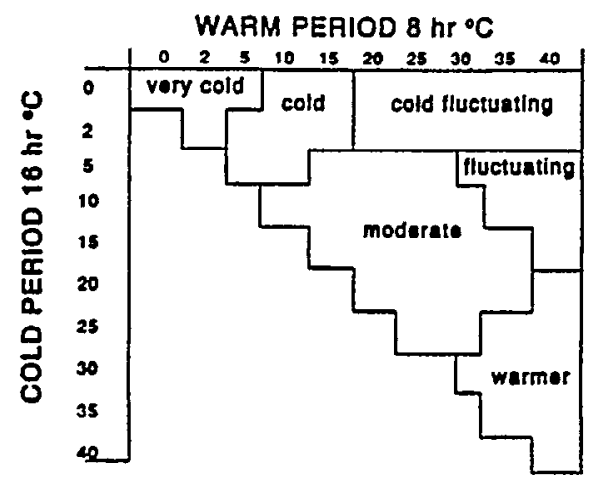

Fig. 2. Temperature regimes reflecting seedbed environments occurring across a wide array of geographic locations. Regimes are based on monitoring studies.

A wide range of temperature conditions occur in fall on seedbeds in the Northern Great Plains region. Findings of this study suggest that while Japanese brome seeds collected in Montana are sensitive to temperature, germination in excess of $50 \%$ occurs over a wide range of temperature regimes. Thus, there is an excellent potential for continued invasion of this species on these Northern Great Plains rangelands. The high level of germination exhibited by afterripened Japanese brome seeds suggest a large portion of the disseminated seeds will germinate completely with available water during late summer and early fall.

\section{Literature Cited}

Baskin, J.M., and C.C. Baskin. 1981. Ecology of germination and flowering in the weedy winter annual grass Bromus japonicus. J. Range Manage. 34:369-372.

Cook, C.W., and L.E. Harris. 1952. Nutritive value of cheatgrass and crested wheatgrass on spring ranges of Utah. J. Range Manage. 5:331337.

Evans, R.A., and J.A. Young. 1970. Plant litter and establishment of alien annual species in rangeland communities. Weed Sci. 18:697-703.

Evans, R.A., and J.A. Young. 1972. Microsite requirements for establishment of annual rangeland weeds. Weed Sci. 20:350-356.

Evans, R.A., D.A. Easi, D.N. Book, and J.A. Young. 1982. Quadratic response surface analysis of seed germination trials. Weed Sci. 30:411 416.

Evans, R.A., H.R. Holbo, R.E. Eckert Jr., and J.A. Young. 1970. Functional environment of downy brome communities in relation to weed control and revegetation. Weed Sci. 18:89-97.

Haferkamp, M.R., J.D. Volesky, M.M. Borman, R.K. Heitschmidt, and P.O. Currie. 1993. Effects of mechanical treatments and climatic factors on the productivity of Northern Great Plains rangelands. J. Range Manage. 46:346-350.

Haferkamp, M.R., M.G. Karl, and M.D. MacNeil. 1994. Influence of storage, temperature, and light on germination of Japanese brome seed. J. Range Manage. 47:140-144.

Hull, A.C., and J.F. Pechanec. 1947. Cheatgrass-a challenge to range research. J. For. 45:555-564.

Hull, A.C., Jr., and W.T. Hansen, Jr. 1974. Delayed germination of cheatgrass seed. J. Range Manage. 27:366-368.

Palmquist, D.E., R.A. Evans, and J.A. Young. 1987. Comparative analysis of temperature-germination response surfaces, p. 97-103. In: G.W. Frasier (ed.), Proc. of Symp. "Seed and seedbed ecology of rangeland plants." 21-23 Apr. 1987, Tucson, Ariz. USDA-ARS, Washington, D.C.

Vegis, A. 1964. Dormancy in higher plants. Annu. Rev. Plant Physiol. 15:185-224.

Whisenant, S.G. 1990. Postfire population dynamics of Bromus japonicus. Am. Midl. Natt. 123:301-308.

Young, J.A., and R.A. Evans. 1982. Temperature profiles for germination of cool season grasses. ARR-W-22. Agr. Res. Ser. USDA, Oakland, Calif.

Young, J.A., E. Martens, and N.E. West. 1992. Germination of bur buttercup seeds. J. Range Manage. 45:358-362. 